IRA-International Journal of Management \& Social Sciences

ISSN 2455-2267; Vol.04, Issue 02 (2016)

Pg. no. 464-470

Institute of Research Advances

http://research-advances.org/index.php/RAJMSS

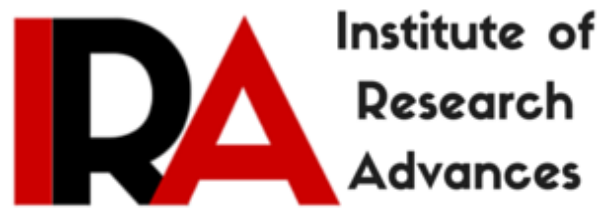

\title{
Equity Share Price Behaviour of Selected Companies with Reference to Construction Industries in NSE
}

\author{
${ }^{1}$ Dr. P. Karthikeyan \\ Associate Professor of Management Studies, \\ Periyar University PG Extension Centre, \\ Dharmapuri -636705, Tamilnadu, India. \\ ${ }^{2}$ S. Dinesh Kumar \\ Part-Time Research Scholar, Bharathiar University, \\ Coimbatore-641046, Tamilnadu, India.
}

Type of Review: Peer Reviewed.

DOI: http://dx.doi.org/10.21013/jmss.v4.n2.p16

\section{How to cite this paper:}

Karthikeyan, P., \& Kumar, S. (2016). Equity Share Price Behaviour of Selected Companies with Reference to Construction Industries in NSE. IRA-International Journal of Management \& Social Sciences (ISSN 2455-2267), 4(2), 464-470. doi:http://dx.doi.org/10.21013/jmss.v4.n2.p16

(C) Institute of Research Advances

\section{(cc) EY-NC}

This work is licensed under a Creative Commons Attribution-Non Commercial 4.0 International License subject to proper citation to the publication source of the work.

Disclaimer: The scholarly papers as reviewed and published by the Institute of Research Advances (IRA) are the views and opinions of their respective authors and are not the views or opinions of the IRA. The IRA disclaims of any harm or loss caused due to the published content to any party. 


\begin{abstract}
Stock market plays a vital role in the economic development of every country whereas there are various factors affecting its performance directly and indirectly. Government of India launched new program recently called Make in India. Under this scheme investment of USD 1 Trillion has been projected for the infrastructure sector until 2017, 40\% of which is to be funded by the private sector. $45 \%$ of infrastructure investment will be directed through a narrow space into construction activity and $20 \%$ set to modernize the construction industry. Based on this above projection from the government, Investors can expect the direct or indirect impact in the share price of construction industries in India. Based on the fact, decided to choose the construction company for this study and the study is to find out the share price behavior analysis for selected company under construction sector which is listed in NSE using simple statistical analysis like Simple moving average and Trend analysis.
\end{abstract}

Behaviour.

Key words: Stock Market, Infrastructure, Foreign Institutional Investors, Construction Industries,

\title{
INTRODUCTION:
}

The Indian capital Market has witnessed a tremendous growth in the recent past. There was an explosion of investor interest during the nineties and an Equity Guilt emerged in statutory legislations has helped the capital market. Foreign Exchange regulation act is one such legislation in this direction.

An important recent development has been the Entry of Foreign Institutional Investors (FII) are participants to the primary and secondary markets for the securities. In the past several years, investments in developing countries have increased remarkably. Among the developing countries India has received considerable capital inflows in recent years. The liberalization policy of the government of India has now started fielding results and the country is poised for a big leap in the industrial and economic growth. The Economy of the country is mainly based on the development of the corporate sectors.

Generally, the security prices reflect the performance of a company. Both economic and noneconomic factors invariably affect stock return behavior. As Cootner (1964) says that "the prices of securities are typically very sensitive, responsive to all events, both real and imagined".

\section{OBJECTIVES OF THE STUDY:}

The following are the objectives of the study;

$>$ To analyze the share price behavior for selected construction companies.

$>$ To predict the Fluctuations for selected construction companies in the stock market using simple statistical analysis.

$>$ To understand the current movement of stocks and to predict the future trend of selected companies under construction sector.

\section{DATA COLLECTION SOURCES:}

This research study is aimed to analyze the equity share price movement in construction industry using simple statistical analysis. The pertained data were collected from the Secondary sources Viz., NSE 
official website. For the purpose of this study, the monthly closing prices of five construction industry listed in National Stock Exchange were taken namely DLF Limited, Oberoi Reality Limited, Prestige Estates Projects Limited, NCC Limited and Ashoka Buildcon Limited and their price movements are computed and studied.

The purpose of this analysis is to take the two years solid data from the official website of National Stock Exchange (NSE) and to predict the market trends in each of the above mentioned companies.

\section{STUDY PERIOD COVERED:}

The Monthly share prices of above mentioned companies were taken for a period of July 2014 to July 2016. The closing prices of share prices were taken and the future price movements were analyzed.

\section{STATISTICAL TOOLS USED FOR ANALYSIS:}

In this study, Simple moving average and Trend analysis were employed to achieve the objectives of the present study.

\section{SIMPLE MOVING AVERAGE:}

A moving average is an indicator that shows the average value a security's price over a period of time. When calculating a moving average, a mathematical analysis of the security's average value over a pre-determined time period is made. As the securities price changes, its average price moves up or down. Investors and policy makers can interpret a moving average by comparing the relationship between the moving averages of the security's price with the security's price itself.

\section{TREND ANALYSIS:}

Trend analysis is rooted in the idea that historical trading trends can give traders an idea of what may happen in the future. Forecasting technique that relies primarily on historical time series data to predict the future. 
IRA-International Journal of Management \& Social Sciences

Table 1: Moving Average of Construction Industry

\begin{tabular}{|c|c|c|c|c|c|c|c|c|c|c|}
\hline \multirow{2}{*}{$\begin{array}{c}\text { Period } \\
\text { (YY - } \\
\text { Month) }\end{array}$} & \multicolumn{2}{|c|}{ DLF Limited } & \multicolumn{2}{|c|}{$\begin{array}{c}\text { Oberoi Realty } \\
\text { Limited }\end{array}$} & \multicolumn{2}{|c|}{$\begin{array}{l}\text { Prestige Estates } \\
\text { Projects Limited }\end{array}$} & \multicolumn{2}{|c|}{ NCC Limited } & \multicolumn{2}{|c|}{$\begin{array}{c}\text { Ashoka Buildcon } \\
\text { Limited }\end{array}$} \\
\hline & $\mathrm{AC}^{*}$ & MA** & $\mathrm{AC}^{*}$ & MA** & $\mathrm{AC}^{*}$ & MA** & $\mathrm{AC}^{*}$ & MA** & $\mathrm{AC}^{*}$ & MA** \\
\hline 14-Jul & 198.25 & - & 260.00 & - & 250.05 & - & 73.20 & - & 127.70 & - \\
\hline 14-Aug & 177.30 & 175.47 & 236.80 & 238.27 & 222.90 & 230.95 & 68.85 & 60.32 & 128.25 & 130.17 \\
\hline 14-Sep & 150.85 & 150.97 & 218.00 & 233.37 & 219.90 & 222.58 & 38.90 & 55.80 & 134.55 & 134.12 \\
\hline 14-Oct & 124.75 & 141.57 & 245.30 & 242.43 & 224.95 & 233.85 & 59.65 & 55.23 & 139.55 & 137.32 \\
\hline 14-Nov & 149.10 & 137.08 & 264.00 & 263.17 & 256.70 & 240.37 & 67.15 & 69.47 & 137.85 & 138.75 \\
\hline 14-Dec & 137.40 & 152.13 & 280.20 & 275.82 & 239.45 & 257.08 & 81.60 & 74.87 & 138.85 & 139.80 \\
\hline 15-Jan & 169.90 & 154.23 & 283.25 & 295.03 & 275.10 & 266.30 & 75.85 & 78.82 & 142.70 & 148.77 \\
\hline $15-\mathrm{Feb}$ & 155.40 & 161.18 & 321.65 & 296.42 & 284.35 & 275.90 & 79.00 & 88.97 & 164.75 & 161.10 \\
\hline 15-Mar & 158.25 & 150.03 & 284.35 & 291.67 & 268.25 & 264.08 & 112.05 & 93.98 & 175.85 & 166.90 \\
\hline 15-Apr & 136.45 & 137.48 & 269.00 & 286.67 & 239.65 & 250.53 & 90.90 & 95.10 & 160.10 & 171.87 \\
\hline 15-May & 117.75 & 123.70 & 306.65 & 282.58 & 243.70 & 243.52 & 82.35 & 83.97 & 179.65 & 172.27 \\
\hline 15-Jun & 116.90 & 116.57 & 272.10 & 280.63 & 247.20 & 236.97 & 78.65 & 81.17 & 177.05 & 180.62 \\
\hline 15-Jul & 115.05 & 114.28 & 263.15 & 253.37 & 220.00 & 223.47 & 82.50 & 77.62 & 185.15 & 182.00 \\
\hline 15-Aug & 110.90 & 121.10 & 224.85 & 253.72 & 203.20 & 212.90 & 71.70 & 76.33 & 183.80 & 179.05 \\
\hline 15-Sep & 137.35 & 121.58 & 273.15 & 261.25 & 215.50 & 207.38 & 74.80 & 75.62 & 168.20 & 172.47 \\
\hline 15-Oct & 116.50 & 122.82 & 285.75 & 273.17 & 203.45 & 207.35 & 80.35 & 77.57 & 165.40 & 173.60 \\
\hline 15-Nov & 114.60 & 115.70 & 260.60 & 271.65 & 203.10 & 200.02 & 77.55 & 77.90 & 187.20 & 184.03 \\
\hline 15-Dec & 116.00 & 108.98 & 268.60 & 257.48 & 193.50 & 194.00 & 75.80 & 72.58 & 199.50 & 193.30 \\
\hline 16-Jan & 96.35 & 100.43 & 243.25 & 247.40 & 185.40 & 176.02 & 64.40 & 67.18 & 193.20 & 189.70 \\
\hline 16-Feb & 88.95 & 100.02 & 230.35 & 238.37 & 149.15 & 169.10 & 61.35 & 67.18 & 176.40 & 180.17 \\
\hline 16-Mar & 114.75 & 109.27 & 241.50 & 250.55 & 172.75 & 163.45 & 75.80 & 71.75 & 170.90 & 161.17 \\
\hline 16-Apr & 124.10 & 121.78 & 279.80 & 264.10 & 168.45 & 175.58 & 78.10 & 75.83 & 136.20 & 148.45 \\
\hline 16-May & 126.50 & 131.42 & 271.00 & 274.03 & 185.55 & 179.80 & 73.60 & 75.32 & 138.25 & 144.40 \\
\hline 16-Jun & 143.65 & 143.82 & 271.30 & 277.77 & 185.40 & 185.47 & 74.25 & 76.53 & 158.75 & 151.80 \\
\hline 16-Jul & 161.30 & - & 291.00 & - & 185.45 & - & 81.75 & - & 158.40 & - \\
\hline
\end{tabular}

(*Average Closing Price;** Moving Average) 
Table 2: Average closing price and Moving average from April 2016 to July 2016 Construction Industry (Amount in INR)

\begin{tabular}{|l|c|c|}
\hline \multicolumn{1}{|c|}{ Company Name } & $\begin{array}{c}\text { Avg Closing } \\
\text { Price }\end{array}$ & $\begin{array}{c}\text { Average } \\
\text { MA }\end{array}$ \\
\hline DLF Limited & 138.89 & 132.34 \\
\hline Oberoi Realty Limited & 278.28 & 271.97 \\
\hline Prestige Estates Projects Limited & 181.21 & 180.28 \\
\hline NCC Limited & 76.93 & 75.89 \\
\hline Ashoka Buildcon Limited & 147.90 & 148.22 \\
\hline
\end{tabular}

Table 3: Future Trend Prediction of Construction Industry (Amount in INR)

\begin{tabular}{|c|c|c|c|c|c|}
\hline $\begin{array}{c}\text { Period } \\
\text { (YY- } \\
\text { Month) }\end{array}$ & $\begin{array}{c}\text { DLF } \\
\text { Limited }\end{array}$ & $\begin{array}{c}\text { Oberoi Realty } \\
\text { Limited }\end{array}$ & $\begin{array}{c}\text { Prestige Estates } \\
\text { Projects Limited }\end{array}$ & $\begin{array}{c}\text { NCC } \\
\text { Limited }\end{array}$ & $\begin{array}{c}\text { Ashoka } \\
\text { Buildcon } \\
\text { Limited }\end{array}$ \\
\hline 16-Apr & 124.10 & 279.80 & 168.45 & 78.10 & 136.20 \\
\hline 16-May & 126.50 & 271.00 & 185.55 & 73.60 & 138.25 \\
\hline 16-Jun & 143.65 & 271.30 & 185.40 & 74.25 & 158.75 \\
\hline 16-Jul & 161.30 & 291.00 & 185.45 & 81.75 & 158.40 \\
\hline 16-Aug & 171.31 & 286.79 & 193.98 & 79.84 & 150.62 \\
\hline 16-Sep & 188.94 & 296.83 & 193.98 & 83.93 & 158.90 \\
\hline 16-Oct & 202.52 & 304.38 & 198.23 & 86.66 & 156.77 \\
\hline 16-Nov & 216.33 & 307.26 & 202.50 & 87.73 & 159.71 \\
\hline 16-Dec & 231.70 & 315.94 & 204.57 & 91.10 & 163.03 \\
\hline 17-Jan & 245.63 & 321.24 & 208.90 & 93.03 & 163.32 \\
\hline 17-Feb & 260.45 & 327.10 & 212.13 & 95.28 & 166.31 \\
\hline 17-Mar & 273.90 & 333.54 & 215.06 & 97.72 & 167.99 \\
\hline 17-Apr & 288.26 & 339.10 & 218.85 & 99.80 & 169.65 \\
\hline 17-May & 302.63 & 345.34 & 221.99 & 102.18 & 172.02 \\
\hline 17-Jun & 317.24 & 351.63 & 225.53 & 104.56 & 173.78 \\
\hline 17-Jul & 331.37 & 357.42 & 228.94 & 106.75 & 175.76 \\
\hline
\end{tabular}




\section{CHART 3.1}

Future Trend Prediction of Construction Industry

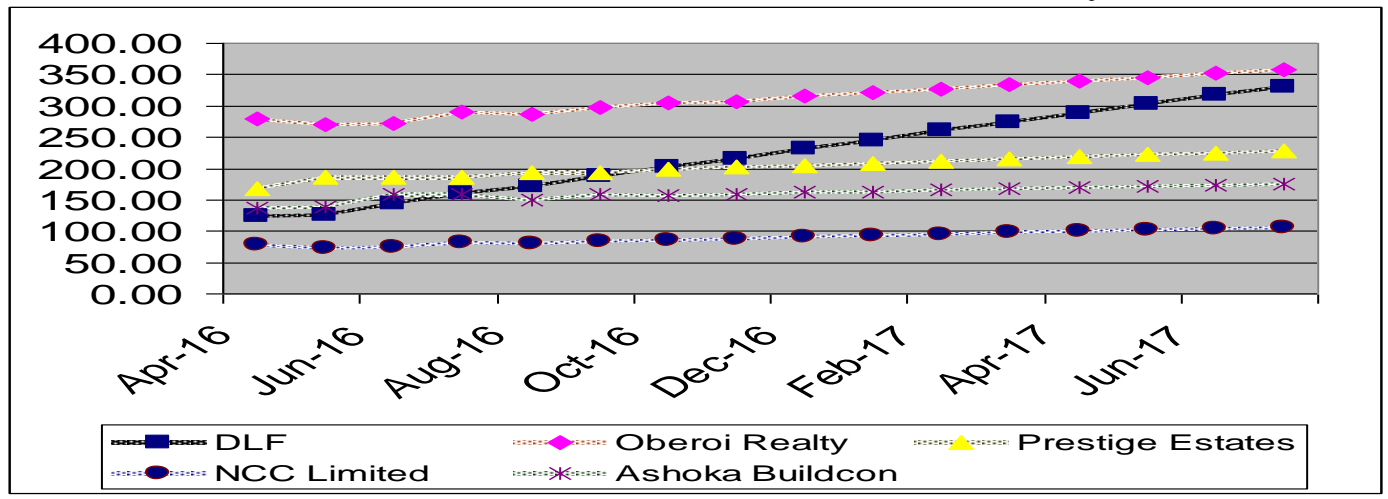

\section{RESULTS AND FINDINGS:}

It is identified from the analysis that, the average closing price of DLF limited from April 2016 to July 2016 is Rs.138.39 which is more than the moving average which indicate the buying signal for DLF Limited and the recent history of DLF Limited closing price from the period March 2016 to July 2016 all the average closing price is more than the moving average. Future trend value of DLF Limited shows the share price will be in the upward trend for the next one year from August 2016 to July 2017. It clear that, the analysis shows the buying signal for DLF.

It is observed from the analysis that, Oberoi Reality Limited average closing price of the script is Rs.278.28. Whereas average moving average is Rs.271.97 and the Future trend value of Oberoi Reality Limited shows the share price will be in the upward trend for the next one year from August 2016 to July 2017. It is clear that the analysis shows the buying signal for Oberoi Reality Limited.

It is Limelighted from the analysis that, the average closing price of Prestige Estates Projects Limited is Rs181.21. Whereas moving average is Rs.180.28 security's price rises above its moving average. It shows the positive sign and Future trend value of Prestige Estate Projects Limited shows the share price will be in the upward trend for the next one year from August 2016 to July 2017. It is clear that, the analysis shows the buying signal for Prestige Estates Project Limited.

It is noted from the analysis that, the NCC limited average closing price is Rs.76.93 and its moving average Rs.75.89 and the closing price is above the moving average and the trend is also in upward and it is clear that the analysis shows the buying sign for this script.

From the analysis, it is identified that, the average closing price of Ashoka Buildcon Limited is Rs.147.90. Whereas moving average is Rs.148.22. Here Moving average is more than closing price. It is clear that the analysis shows the selling signal and also future trend value of Ashoka Buildcon Limited for the month of August 2016 is in negative trend.

\section{SUGGESTIONS:}

The present study covered Moving average and Trend analysis for DLF limited, Oberoi Realty limited, Prestige Estates, NCC limited and Ashoka Buildcon limited under construction industry in NSE. When the security's price rises above its moving average it indicates the Buying signal and when the security's price falls below its moving average it indicates the selling signal and Trend analysis is used in an attempt to predict the future movement of a stock on the basis of historical price data. 
Moving average and Trend analysis for DLF Limited, Oberoi Realty Limited, Prestige Estates Projects Limited, and NCC limited shows the buying signal for the security, but in case of Ashoka Buildcon Limited average closing price is less than the Moving average. It clear that, it shows the selling signal for the script.

While analyzing DLF Limited, Oberoi Realty Limited, Prestige Estates Projects Limited and NCC limited share price it shows the positive trend but while predicting the future trend DLF limited share price may reach up to Rs.331.37 during July 2017 which is nearly 100 percent return to the investors and the average moving price of DLF Limited is healthier than the other scripts. Hence it is suggested to invest in DLF Limited.

\section{CONCLUSION:}

In India most of the sector's required huge amount of investment. Funds are raised through the issue of shares in primary market and other source. An investor is satisfied from the reasonable amount of return from investment in shares and also the investors are motivated to buy the shares from the stock market for investments.

An investor can only succeed in his investment when they are able to select the right share in right sector. The investors must watch the situations keenly in the market like political, economy, company progress, industrial profile, returns, and the risk involved in a share before invest in the share. This study made an attempt to help the investors to know the behavior of the share prices for five companies in construction industry which helps them in succeeding in their investment activities.

\section{REFERENCE:}

1. Avadhani V.A., "Investment Management", Himalaya Publishing House, NewDelhi, $2^{\text {nd }}$ Edition, 1999.

2. Bhalla V.K., "Investment Management", Security Analysis and Portfolio Management, S.Chand \& Co Ltd, New Delhi, $2^{\text {nd }}$ Edition, 1997.

3. Gupta.S.P., "Statistical Methods", Sultan Chand \& Co, $2^{\text {nd }}$ Edition, 1998.

4. Kothari.C.R., " Research Methods and Techniques", Wishwa Prakashan Publishing, New Delhi, 1990..

5. Prasanna Chandra, "Financial Management-Theory and Practice", Tata Mc Graw Hill, International Edition, $5^{\text {th }}$ edition, 2000. 